\title{
Findings on Fluorine-18 Fluorodeoxyglucose Positron Emission Tomography/Computed Tomography in a Patient with Malignant Pheochromocytoma
}

\author{
Malign Feokromasitomalı Bir Hastanin Flor- 8 Florodeoksiglukoz \\ Pozitron Emisyon Tomografi/Bilgisayarlı Tomografi Bulguları
}

\author{
Pelin Ozcan Karal, Taylan Kara2, Gonca Kara Gedikl, Oktay Sari3, Ozlem Sahin3 \\ I Selcuk University Selcuklu Medical Faculty, Department of Nuclear Medicine, Konya, Turkey \\ 2Beyhekim State Hospital, Department of Radiology, Selcuklu, Konya, Turkey \\ 3Selcuk University Meram Medical Faculty, Department of Nuclear Medicine, Konya, Turkey
}

\begin{abstract}
Pheochromocytomas are rare tumors arising from chromaffin cells of the sympathoadrenal system and $85 \%$ of them are located in the adrenal medulla. Malignant pheochromocytomas account for $10 \%$ of all pheochromocytomas. Since clinical, biochemical and histopathological features can not reliably distinguish malignant from benign tumors, malignancy is established in the presence of distant metastases. Although in some cases, metastases may develop during follow-up, most of these tumors have metastatic disease at initial presentation. In this case report, detection of distant metastases and recurrence developed during follow-up with 18-flouro-deoxyglucose positron emission tomography/computed tomography (FDG PET/CT) in a patient with malignant pheochromocytoma was presented. (MIRT 201 1;20:67-69)

Key words: Pheochromocytoma; FDG PET/CT
\end{abstract}

\section{Özet}

Feokromasitomalar sempatoadrenal sistemin kromafin hücrelerinden köken alan nadir tümörlerdir ve \%85'i adrenal medullada lokalize olur. Malign feokromasitomalar tüm feokromasitomaların \%10'unu olușturur. Klinik, biyokimyasal ve histopatolojik yöntemlerin hiçbiri malign tümörleri benign tümörlerden ayıramadığından, malignite uzak metastaz varlığında tanımlanır. Her ne kadar bazı vakalarda metastazlar takip sırasında gelișebilirse de, vakaların büyük çoğunluğunda ilk tanı anında metastatik hastalık mevcuttur. Bu olgu sunumunda, malign feokromasitomalı bir hastada takip sırasında rekürens ve uzak metastazlarının 18-florodeoksiglukoz pozitron emisyon tomografi/bilgisayarlı tomografi (FDG PET/BT) ile saptanması sunulmuștur. (MIRT 201 1;20:67-69)

Anahtar kelimeler: Feokromasitoma; FDG PET/BT

\section{Introduction}

Pheochromocytomas are rare tumors arising from chromaffin cells of the sympathoadrenal system and $85 \%$ of them are located in the adrenal medulla. Malignant pheochromocy- tomas account for $10 \%$ of all pheochromocytomas. Since clinical, biochemical and histopathological features can not reliably distinguish malignant from benign tumors, malignancy is established in the presence of distant metastases. In this case report, detection of distant metastases and recurrence devel-

Address for Correspondence: Pelin Ozcan Kara, Selcuk University Selcuklu Medical Faculty, Department of Nuclear Medicine, Selcuklu, Konya, Turkey Phone: +90 33224150 00/44077 E-mail: ppelinozcan@gmail.com

Received: 22.03.2010 Accepted: 26.05.2010 
oped during follow-up with 18-flouro-deoxyglucose positron emission tomography/computed tomography (FDG PET/CT) in a patient with malignant pheochromocytoma was presented.

\section{Case Report}

A 50 year old man with a history of pheochromocytoma for six years was presented with recurrence. He had biopsy proven pheochromocytoma and two operations for recurrence, the last of which was two years ago. Left adrenal soft tissue mass with a diameter of $11 \mathrm{~mm}$ and lymph nodes located at paraaortic-paracaval region were shown on CT imaging. Further functional imaging with FDG PET/CT depicted a nodular lesion with mildly increased FDG uptake localized on left adrenal gland which was not detected on his previous imaging exams (Figure 1 arrows). Maximum standardized uptake value (SUVmax) of the lesion was calculated as 2.86 . Increased FDG uptake (SUVmax:19.44) in paraaortic and

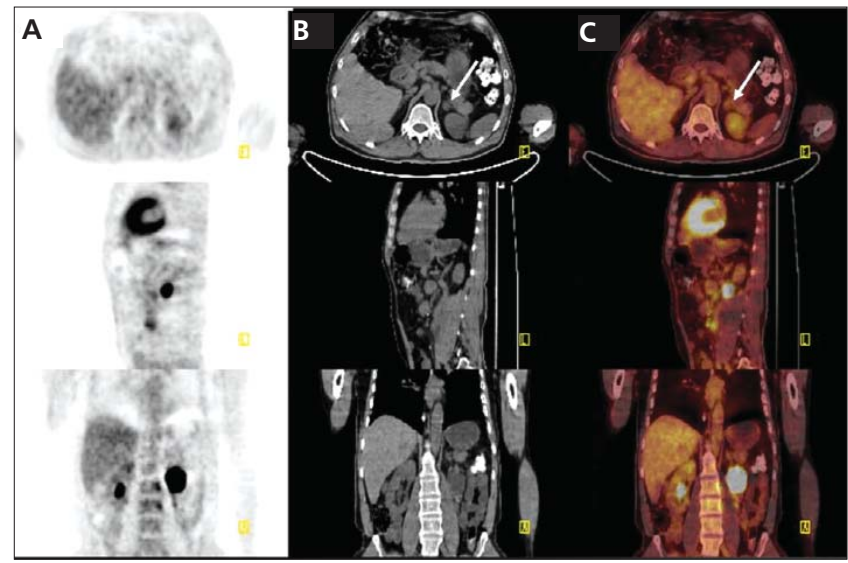

Figure 1. FDG PET/CT scan. Axial, sagittal and coronal PET (A), unenhanced $C T(B)$, Fused $(C)$ images illustrate a nodular lesion with mildly increased FDG uptake localized on left adrenal gland (arrows) (SUVmax: 2.86)
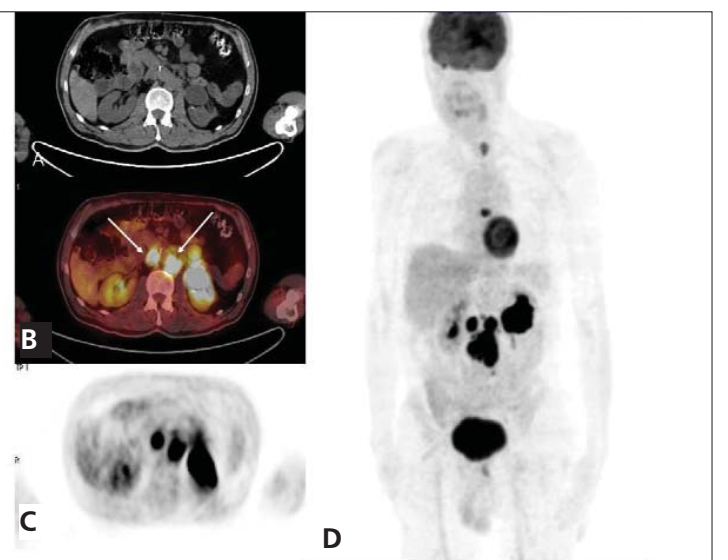

Figure 2. FDG PET/CT scan. Axial unenhanced $C T(A)$, Fused (B), PET (C) and PET/CT MIP (D) images identified both recurrence at the site of original disease and metastatic regions. Paraaortic and paracaval lymph nodes are shown with arrows paracaval lymph nodes was also observed ( Figure 2 arrows). Additionally, metastatic sclerotic lesion on $7^{\text {th }}$ thoracal vertebra with increased FDG uptake (SUVmax: 9,23) was detected (Figure 3 arrows).

\section{Literature Review and Discussion}

Recently, FDG PET /CT have emerged as an important clinical diagnostic tool in a variety of malignancies. Whether benign or malignant, most pheochromocytomas are metabolically active and accumulate FDG. Shulkin et al. detected pheochromocytoma with FDG PET in 22 of 29 patients (76\%) (1). Magnetic resonance imaging (MRI) provides excellent anatomic detail and is more accurate than CT especially in detecting extra-adrenal pheochromocytomas. MRI lacks in sensitivity as availability of whole-body imaging may be difficult. CT is accurate in detecting primary adrenal pheochromocytomas with high sensitivities, although specificity is low and less successful in detection of recurrent disease. Whole-body CT scanning is impractical for routine use due to radiation exposure. Therefore, $\mathrm{CT}$ is limited in the detection of multifocal disease. In a study by Timmers et al. FDG PET was found useful with a $100 \%$ per patient sensitivity and a $97 \%$ per body region sensitivity for pheochromocytomas, better than either CT or MRI and especially useful in the detection of distant metastasis (2). In a study by Mann et al, both C-1 1 HED and F-1 8 FDG were able to localize more lesions in a more timely fashion than I-131 MIBG (3). Several studies have shown that most pheochromocytomas accumulate FDG $(12,3,4,5)$. However, FDG uptake is found in a greater percentage of malignant than benign pheochromocytomas (1). In this case, recurrent adrenal lesion, lymph node involvement and bone metastasis were successfully detected by FDG PET/CT. In cases whom extraadrenal and/or metastatic disease is suspected, and anatomical imaging results are equivocal or negative, FDG PET/CT should be used to assess the extent of disease.

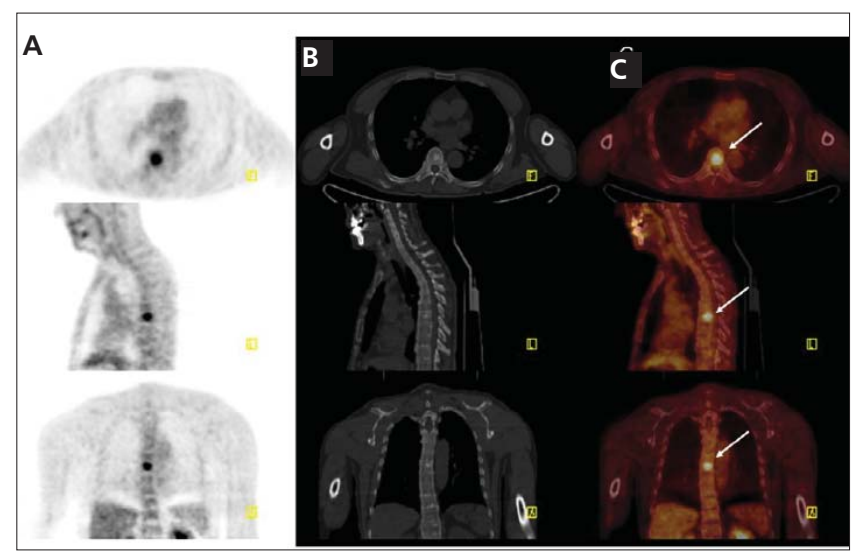

Figure 3. FDG PET/CT scan. Axial, sagittal and coronal PET (A), unenhanced $C T(B)$, Fused $(C)$ images illustrate metastatic sclerotic lesion on 7th thoracal vertebra with increased FDG uptake (arrows) (SUVmax: 9,23) 


\section{References}

1. Shulkin BL, Thompson NW, Shapiro B, Francis IR, Sisson JC. Pheochromocytomas: imaging with 2-[Fluorine-18]fluoro-2-deoxy-Dglucose PET. Radiology 1999;212:35-41.

2. Timmers HJ, Kozupa A, Chen CC, Carrasquillo JA, Ling A, Eisenhofer G, Adams KT, Solis D, Lenders JW, Pacak K. Superiority of fluorodeoxyglucose positron emission tomography to other functional imaging techniques in the evaluation of metastatic SDHB-associated pheochromocytoma and paraganglioma. J Clin Oncol 2007;25(16):2262-2269.
3. Mann GN, Link JM, Pham $P$ et al. [1 1C]metahydroxyephedrine and [18F]fluorodeoxyglucose positron emission tomography improve clinical decision making in suspected pheochromocytoma. Ann Surg Oncol. 2006;13(2):187-197.

4. llias I, Pacak K. Anatomical and functional imaging of metastatic pheochromocytoma. Ann N Y Acad Sci. 2004; 1018:495-504.

5. Ilias I, Yu J, Carrasquillo JA, et al. Superiority of 6-[18F]-fluorodopamine positron emission tomography versus [1311]-metaiodobenzylguanidine scintigraphy in the localization of metastatic pheochromocytoma. J Clin Endocrinol Metab. 2003;88(9):4083-4087. 